\title{
印刷技術によるビスマステルライド薄膜の生成
}

\section{Printed bismuth telluride thin films and those thermoelectric properties}

\author{
○学 橋本 佳弘（九州エ大院） 加藤 邦久（リンテック） 正 宮崎 康次 (九州工大)
}

Yoshihiro HASHIMOTO, Kyushu Institute of Technology, 1-1 Sensui-cho, Tobata-ku, Kitakyushu, Fukuoka Kunihisa KATO, Lintec Corporation, 5-14-42 Nishiki-cho, Warabi-shi, Saitama

Koji MIYAZAKI, Kyushu Institute of Technology, 1-1 Sensui-cho, Tobata-ku, Kitakyushu, Fukuoka

Key Words: Printing method, Thermoelectric, Thin film, Conductive polymer

\section{1. 緒言}

近年，環境問題などからエネルギーハーベスティング技 術が注目されている(1). 我々は, その中で熱電発電に着目 し，室温付近で最も効率の高い熱電半導体であるビスマス テルライド(2)(3)を用いて熱電半導体の作製を行ってきた。 従来のフラッシュ蒸着法や MOCVD 法や PVD 法などの成 膜法は高コストで大面積，大量生産に不向きであった。 そ こで，我々は印刷技術に着目した．スピンコートやインク ジェットと言った印刷技術は, 従来の物理蒸着法などに比 ベ, 迅速かつ大面積化も可能で材料利用効率も高いので, 低コスト化にも適している。熱電半導体もナノ粒子を用い ることでスピンコートやインクジェットと言った印刷技術 による成膜が可能となる，そこで，本研究では微粒子を作 製し，導電性高分子などを混合して，インクを作製するこ とで，印刷技術によりビスマステルライド薄膜の生成を行 い，作製した薄膜の熱電特性の評価を行った.

\section{2. 実験}

\section{1 微粒子の作製}

本研究では, 微粒子を作製するために, 湿式ビーズミル 法を用いた。 まず，出発材料として平均粒径 $20 \mu \mathrm{m}$ のビス マステルライド粒子を用意した．湿式粉砕のために溶媒と して凝集を防ぐために分散剤 (DisperBYK-192) を $1 \mathrm{wt} \%$ 添加したエタノール $500 \mathrm{~g}$, ビーズには粒径 $0.3 \mu \mathrm{m}$ の $\mathrm{ZrO}_{2}$ 粒子 $500 \mathrm{~g}$ を用意して，ビスマステルライド粒子とエタノ 一ルと $\mathrm{ZrO}_{2}$ ビーズの混合液を湿式ビーズミル機 (アシザ ワ・ファインテック株式会社 MINI CER) により $3900 \mathrm{rpm}$ で 6 時間運転して微粒子を作製した．作製した微粒子を回 収して,アニール装置を用い $\mathrm{Ar}$ 雲囲気中で, $60^{\circ} \mathrm{C}, 360 \mathrm{~min}$ 加熱, 乾燥させた。粉砕した結果平均粒径 $3 \mu \mathrm{m}$ の微粒子が 得られた。粉砕した微粒子の SEM 画像を図 1 に示してお り，粉砕した微粒子からナノ粒径の粒子も得ることが出来 た.

\section{2 熱電薄膜の生成}

粉砕したビスマステルライド微粒子を用いてインクを作 製した.インクには, PEDOT:PSS 及びバインダーとしてグ リセリンを用いた．作製したインクをスプレー印刷により アルミナ基板上に成膜した. 成膜後 $\mathrm{Ar}$ 雾囲気中で $130{ }^{\circ} \mathrm{C}$ で $10 \mathrm{~min}$ 乾燥させた。作製した熱電薄膜は, ゼーベック 係数と電気伝導率を測定して評価した。ゼーベック係数は 薄膜の片側を加熱し，もう一方を放熱しながら両端の電位 差と温度差を測定を行い，電気伝導率は 4 端子法により測 定を行った。

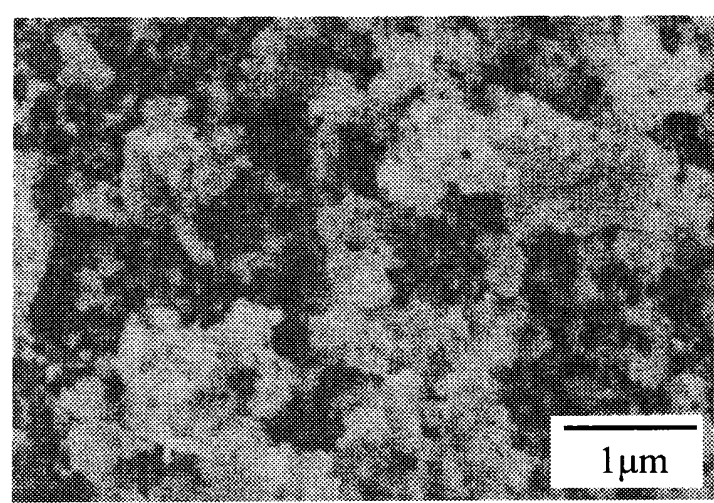

Fig.1 SEM micrograph of bismuth telluride nanoparticles.

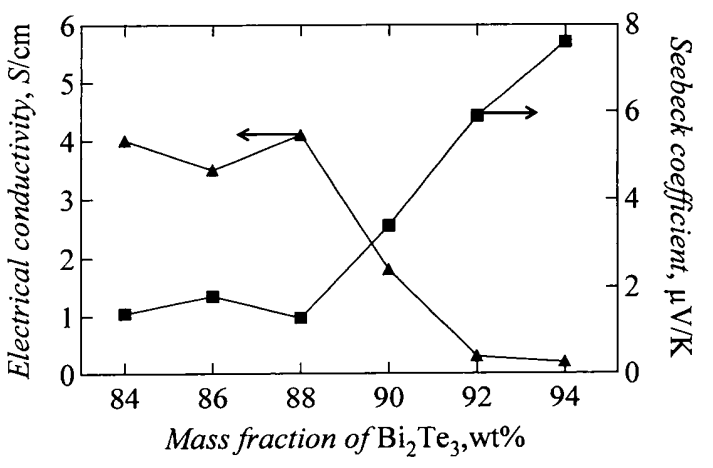

Fig. 2 Electric conductivity and Seebeck coefficient of P-type bismuth tellride thin film.

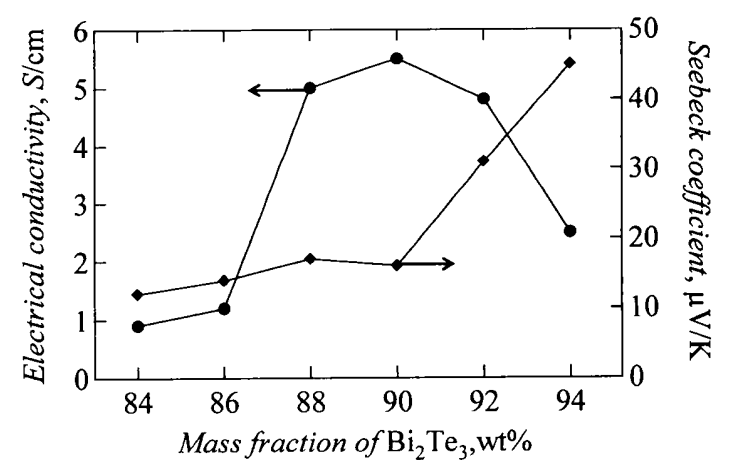

Fig.3 Electric conductivity and Seebeck coefficient of $\mathrm{N}$-type bismuth tellride thin film. 


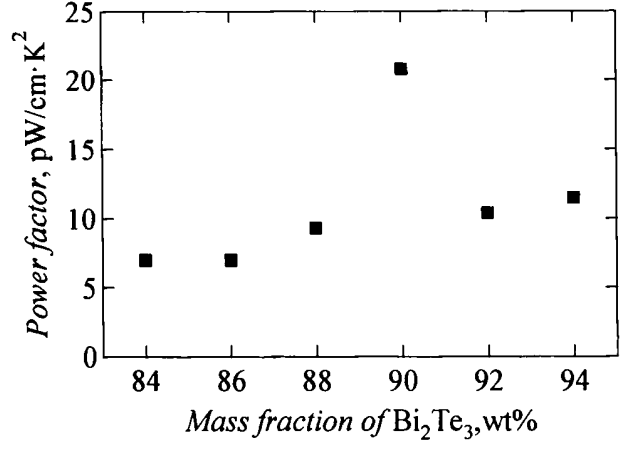

Fig.4 Power factor of PEDOT:PSS mixed with P-type bismuth tellride thin film.

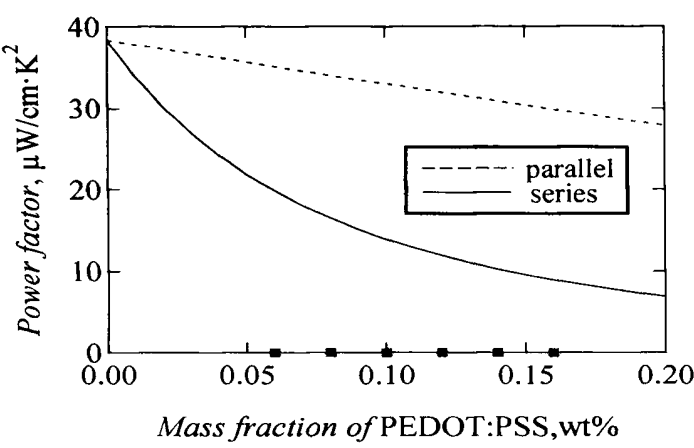

Fig.6 Power factor of PEDOT:PSS mixed with P-type bismuth tellraide in parallel and series models.

\section{3. 実験結果と考察}

作製したビスマステルライド薄膜の電気伝導率及び，ゼ 一ベック係数を測定したものを図 2,3 に示す. 横軸はビス マステルライドの重量パーセント濃度であり，縌軸はそれ ぞれ，電気伝導率，ゼーベック係数を示している．グラフ より， $\mathrm{p}, \mathrm{n}$ 型ともに重量パーセント濃度が增えるにつれて ゼーベック係数の増加が見られ，逆に電気伝導率は低下し た。これは，ゼーベック係数と電気伝導率はトレードオフ の関係にあるからである。電気的特性であるP.F.を図 4, 5 に示した. グラフより図 2，3のトレードオフの関係から， $\mathrm{p}$ 型では $90 \mathrm{wt} \%, \mathrm{n}$ 型では $94 \mathrm{wt} \%$ で P.F.は最大となった。

また，今回作製した複合材料における計算值と実験值を比 較したグラフを図 6，7 亿示す。横軸は PEDOT:PSS の重量 パーセント濃度で, 縦軸は P.F.をとっている. 計算值を求 めるにあたり，以下の式を用いた。

Series model

$$
\begin{aligned}
& S=\frac{S_{1} \frac{1}{\kappa_{1}} \cdot x}{\frac{1}{\kappa_{1}} \cdot x+\frac{1}{\kappa_{2}}(1-x)}+\frac{S_{2} \cdot \frac{1}{\kappa_{2}} \cdot x}{\frac{1}{\kappa_{1}} \cdot x+\frac{1}{\kappa_{2}}(1-x)} \\
& \sigma=\frac{\sigma_{1} \sigma_{2}}{x \sigma_{2}+(1-x) \sigma_{1}}
\end{aligned}
$$

Parallel model

$$
\begin{aligned}
& S=\frac{S_{1} \cdot \sigma_{1} \cdot x+S_{2} \cdot \sigma_{2} \cdot(1-x)}{\sigma_{1} x+\sigma_{2}(1-x)} \\
& \sigma=\sigma_{1} x+\sigma_{2}(1-x)
\end{aligned}
$$

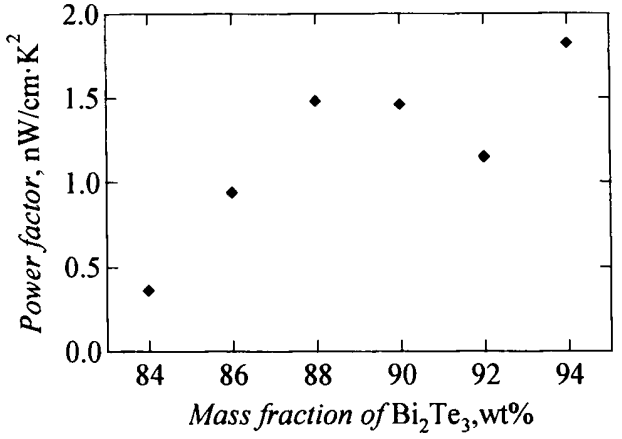

Fig.5 Power factor of PEDT:PSS mixed with N-type bismuth tellride thin film.

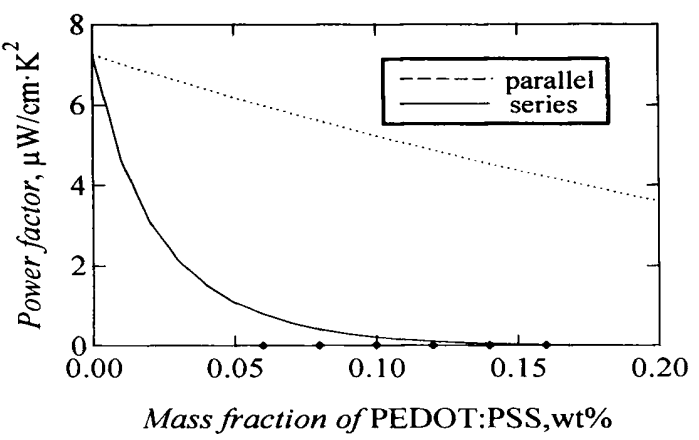

Fig.7 Power factor of PEDOT:PSS mixed with N-type bismuth tellraide in parallel and series models.

$\mathrm{p}, \mathrm{n}$ 型ともに計算値より小さくなった．計算値と比較する と特に電気伝導率の低下が著しかった。この原因として材 料自体の酸化が考えられる. 粉砕後の微粒子の組成を EDS により分析した結果, 微粒子の酸化が確認できた。粉砕前 微粒子では酸化は確認できなかったので，粉砕過程におけ る酸化と考えられる. それによって，粒子境界面での電気 抵抗が増大し，大幅な電気伝導率の低下につながったと考 えられる、また，今回は単純に材料を混合させただけのも のを成膜したために，各材料界面での抵抗も大きかったと 考えられる。

\section{4. 結言}

湿式ビーズミルを用いてビスマステルライド微粒子の作製 をした。作製した微粒子を用いて，インクを調合して熱電 薄膜の作製, 熱電特性の評価を行った。導電性高分子材料 を添加することで，印刷技術によるビスマステルライド薄 膜の作製が出来た．導電性高分子材料の添加により印刷技 術への応用が可能であることが分かった。 今後としては, 微粒子作製時の酸化を防ぐために，有機溶媒の選定や分散 剤の検討, 還元雰囲気下での粉砕を行うなどプロセスの再 検討をする必要がある.

\section{参考文献}

（1）舟橋良次：「熱電変換技術の基礎と応用」，(2011）1-6.

(2) Toprak M. S. et al., 2004 Adv. Funct. Mater 141189.

(3) Song D. W. et al., 2004 Appl. Phys. Lett. 841883. 